\title{
The Winding Path Back to School: Hidden Obstacles to Higher Education for Low-Income Single Mothers
}

\author{
Amanda Freeman
}

Boston College

\begin{abstract}
This paper explores obstacles to the pursuit of higher education for low-income single mothers in the United States. Findings are based on a three-year qualitative study, including 66 in-depth interviews with 37 low-income single parents who were pursuing educational goals through an anti-poverty program in Boston, Massachusetts. Respondents were questioned about their past and current experiences, goals, motivation, and fears related to post-secondary education. All mothers interviewed believed that getting a college degree would help them to secure employment and move their families out of poverty. Findings revealed institutional and practical obstacles to their pursuit of higher education, including conflicting advice from "experts" and difficulty retaining public benefits while attending school. The primary obstacles that emerged were categorized as follows: (a) winding paths and dead ends, (b) difficult transitions, (c) short-sighted decisions, and (d) inflexible institutions. Also evident among interviewees were misconceptions about the policies and practices of institutions of higher education, such as not predicting the difficulty of transferring credits between schools and lack of understanding about differences between degree programs. These obstacles have yet to be explored in literature about higher education for low-income parents. Policy and practical implications for higher education as a route out of poverty are discussed.
\end{abstract}

Keywords: Higher education, poverty, low-income families, qualitative research

\section{Introduction}

Education is one of the most effective ways for low-income single mothers to increase their earning capacity and gain access to highly skilled, quality, sustainable employment (Adair and Dahlberg 2002; Institute for Women's Policy Research (IWPR) 2008; Strawn and Martinson 2000). Single mothers with dependent children are the most likely of any demographic group in the United States to be poor (Olson and Banyard 1993; Seecombe and Walters 1998). Attaining high school, college and other forms of education allows access to higher lifelong earnings and employment benefits. Education also makes low-income women less likely to rely on public benefits for their economic wellbeing (Adair 2001). Pursuing educational opportunities has been shown to improve the self-esteem and job prospects of low-income single mothers (IWPR, 2008) and to positively impact the educational attainment of their children (Jimerson, Egeland and Two 1999). Still, very few low-income single mothers actually earn college degrees in the United States. As such, it is of paramount importance to add to the dearth of research about lesser known obstacles to the educational achievement of low-income single mothers.

\section{Recognized Obstacles to Higher Education for Low-Income Single Mothers}

Perhaps the most obvious and well-documented obstacle to the educational achievement of low-income single mothers is financial stress. College tuition is expensive even for middle class and wealthy Americans, and low-income single mother-headed families are already under tremendous financial strain. Add to this strain, the reality that welfare benefits could be to be taken away if a recipient is attending school or attending school for too long. Furthermore, financial aid and scholarship applications, which have the potential to alleviate some financial stress, create their own maze of deadlines and forms for overwhelmed single parents. 
The prospect of going back to school also raises the issue of finding convenient, affordable, quality childcare. Classes are often offered at different times during the day or evening on alternating days of the week, and they change every semester, making it difficult to negotiate a set schedule with a sitter or daycare center. Many struggle fulfill work and family responsibilities while patching together childcare arrangements to cover classroom and working hours. (Mason 2002; Bullock and Limbert 2003; Deprez, Butler and Smith 2004; Christopher 2005). Even those students who qualify for subsidized childcare often have difficulty retaining childcare vouchers when they return to school. At the same time, "non-traditional" student mothers require longer periods of time to complete degree programs, which come into conflict with the time limits imposed by many public assistance programs. Pearson (2007) found that because of Georgia's 20-hour work requirement to receive welfare benefits, many students eventually dropped out.

The Personal Work Opportunity Reconciliation Act (PRWORA) passed by Congress in 1996 as part of "welfare reform" severely limited the ability of low-income women to pursue educational opportunities. Temporary Assistance for Needy Families (TANF), implemented requirements that capped lifetime benefits, required recipients return to work, and restricted the classification of education as work. Since PRWORA was passed in 1996, drastically fewer welfare recipients have pursued higher education. Researchers tracking the college enrollment of welfare recipients since 1996 have reported decreases between 29 and 82 percent (Polakow 2004, 8; IWPR 1998). In 1995, more than 27,000 welfare recipients were enrolled in classes at the City University of New York (CUNY). By 2000, that number had decreased to 5,000 (Pearson 2007, 725; Cox and Spriggs 2002) where it remains.

\section{Methods}

This research took place over a three-year period, as part of a larger study on lowincome single parents who were participants in a community based antipoverty program in Boston. The program targeted single parents living in public housing who were attempting to go back to school and move "up and out." The qualitative portion of the research, upon which this paper is based, included annual interviews with participants and ethnographic field notes. Interviewees were asked about their educational plans for themselves and their children, as well as their day-to-day experience pursuing work and school.

In all, 66 interviews were conducted with 37 unique participants, and seven interviews were conducted with the four primary staff members of the antipoverty program. The participants were all mothers (with one single father participating for one year) who ranged in age from 26 to 55 and were raising between one and four children. Their children ranged in age from newborn to adult (with an average of 1.7 children per family). Data about the participants' racial/ethnic background was recorded as follows: 13 were White, 15 were Black or African-American, eight were Hispanic/Latino, and one was Asian. The majority of participants lived in public housing developments in South Boston, though this was not a formal requirement. All participants were interviewed annually after they had taken part in the program for a minimum of six months. Each year, researchers applied for and received IRB approval to conduct the interviews with participants. 
The research and analytical approach were guided by principles of feminist inquiry, specifically, placing the lived experiences of the low-income single mothers at the center of the analysis. Researchers here were guided by empathy for the women, taking into account conditions of inequality and oppression while recording and analyzing their stories Dorothy Smith (1997) points to the importance of learning about society from this type of standpoint on the sidelines.

\title{
Results and Discussion
}

In all, we identified four major obstacles to the women's pursuit of higher education: 1). Winding paths and dead ends, 2). Difficult transitions, 3). Short-sighted decisions, and 4). Inflexible institutions. While these obstacles included some elements typically explicated in literature about higher education for low-income women, few have been explored through in-depth, qualitative study.

\section{Winding Paths and Dead Ends}

Collectively, the women interviewed here logged hundreds of post-secondary classroom hours, but many of those hours were never counted towards degrees. Instead of cumulating in a degree or professional skill set, hours were often logged in vocational programs that did not lead to jobs. Credit hours were lost when they changed degree programs, in effect stretching out the length of time needed to complete a given degree. The "career" track taken by most of the interviewees was fluid and, at times, dictated by paperwork, deadlines, logistics, and advice from friends. Kim, a mother of two, was told by a friend there were lots of high paying jobs available in the medical field, although she worried she was not "a blood and guts type person." This is how she described her plans,

\begin{abstract}
“I'm starting next Friday for a certified nurse assistant, and in January I'll start the medical assistant program. The CNA is just something to fill in right now until I actually go to school for the medical assistant. I'd definitely rather do that than the certified nurse assistant, but you know, this way I'll have two different certificates... Nothing else really interested me that much. I just don't even know if this is something I really want to do, but I don't think I will really know until I start the classes. I'll just have to wait and see.”
\end{abstract}

Once she started classes, Kim realized a career in the medical field would not work for her and said she was looking for another trade. In many cases, taking a job they believed would provide the fastest route to a sustainable wage led the women to pursue fields for which they were ill-equipped in terms of their personal interests and experience. In turn, this led to changes in their course of study.

\section{Difficult Transitions}

Another interviewee, Sheila, encountered a setback when she first returned to school and realized that none of the credits from a two-year Associates degree in legal administration, which she'd earned years ago, were transferrable. 
"You'd think I'd be further along, because I have an Associates degree already...but actually my degree doesn't help at all. I have to start over as a freshman everywhere, because the school where I got my degree was not accredited. Nobody takes their credits, and I didn’t know that.”

This situation was common among the women interviewed. Of those who reported transferring colleges or switching programs, all reported losing some credits in the transition. One mother said, "When I first got to the new school, I was upset because I already took some classes and I was going to have to take them over again."

In addition, all students who earned degrees or certificates from non-accredited schools reported a lack of understanding that losing credits was a possibility. One mother of a young son said,

"I have a certificate in Marketing, but they (her new school) wouldn't take that...because it’s like a degree in itself I guess. I didn't know. I don't really understand that, because I got a certificate. So anyway, I am pretty much starting from scratch.”

Interviewees said they did not understand they were earning non-transferrable, standalone degrees. Most did not understand the model of college as a business or the ways in which their winding paths would impact their ability to get a degree.

\section{Short-term Degree Decisions}

As poor mothers, all interviewees expressed the primacy of providing for their children. In order to provide and care for their children, they wanted to pursue whatever educational program would lead them into a sustainable job in the least amount of time. Laura, a mother of two living in public housing, learned about a local for-profit, preprofessional school online. The ads she saw promised graduates would "land you a job within six months of graduation," so she had taken out loans to pay for the classes. When I spoke with her, she had completed the program more than a year before and was still waiting for the school's career services center to return her calls and help her find the promised job.

Even when interviewees did manage to complete Certificate or specialized Associate degree programs, many reported the degree had not impacted their job prospects. One mother with a six-year-old son, who had recently moved out of public housing, said, "I went to a two-year college for my associates in medical assistant, which was really kind of useless...I wound up going back into medical billing, because medical assisting didn't pay as much as medical billing once you had experience... "With several years experience, she did not earn enough to pay rent.

Many interviewees expressed the fear that "time is running out," so they chose programs that were currently available to them. However, several of the respondents eventually circled back to their original program choice or career choice after spending time and money pursuing other opportunities. The first year I spoke with Emma she was working at a local hospital, working to gain acceptance into a nursing program. The next year she said, "I am still trying for the nursing program, but it was closed. Now I have been going to school for my Associates in surgical tech. I applied for RN, 
radiology and ultrasound to give me a better chance, but I am still waiting for them to call me.” By the third year, Emma was closer to completing her Associates in surgical tech, but was still trying to get into nursing, what she "really wanted to do."

\section{Inflexible Institutions}

Many of the degree programs described by interviewees did not allow part-time status, and non-profit and community often required adherence to strict time limits for completion, despite the fact that single mother students often take longer to complete degree programs. One of the mothers interviewed, Lilah, who struggled with depression, was dropped from a scholarship program designed for low-income single mothers because she was taking too long to complete her degree, despite receiving high grades in her classes. Studies show unmarried mothers are prone to mental illness including anxiety and depression (McGrath, Keita, Strickland and Russo 1990; Quinn and Allen 1989). In order to finish on time, Lilah would have had to take five classes during one semester while taking care of her son.

Overall, interviewees reported that their schools were not equipped to help them arrange class schedules around parenting and work obligations or to assist with childcare, which all of the interviewees with young children mentioned as an obstacle to their education. Roughly half of interviewees reported some family support available to help with childcare while they went to school. One interviewee said, "Well this program is at night...so I'd go to the school at night. It (childcare) is not a problem because I had my family, which is huge, to watch him." Women who were without support from family members reported difficulty in securing childcare. Five of the women said they took classes online so they would not have to hire childcare help, but all of those who took online classes said it was very difficult to do schoolwork and listen to lectures while their children were at home.

Even those with childcare vouchers had difficulty retaining consistent care when they went back to school. One mother said, "My time is up. I can't get no more childcare vouchers while being in school. They want me to go to work or nothing at all." According to another interviewee, "I finally got the voucher after waiting many years. But I have to work for thirty hours or be in school full-time to keep the voucher. But I was working twenty and going to school, so it won't work." Many of the women expressed confusion about the way in which school hours "counted" towards retaining a childcare voucher. According to Mia,

\footnotetext{
"They just sent me a notice for childcare termination because they said some of my classes aren't like classes where you go and you sit with the teacher for two hours. They were trying to give me trouble but there is just a lot of confusion because like I don't know. I am in school full-time, but what they don't get is that like for college like, the class will be 3 hours long, but the teacher will tell you, you need to do 6 hours at the school altogether, like literally they want you to sign in and be studying for 3 hours during week but it's not like with the teacher. So there is like no way for them to say yeah, you were sitting in front of me for all this time."
}

Three interviewees sought legal assistance to retain childcare benefits while attending school. Samantha was told by a caseworker that she could keep her benefits if she added 
two classes per semester to become a full-time student, but she said, "I just cannot do that. I can't handle two classes with my kids and everything else, that's it, you know? I tried to do before, and it was just too much." Many expressed frustration at the lack of support for their pursuit of education from benefit programs.

When low-income single mothers attain college degrees, they are less likely to rely on public benefits (IWPR 2008). However, public benefit programs often make it difficult for low-income women to attend school while continuing to receive childcare vouchers and cash assistance, which allows their families to subsist. Welfare reform was considered, by many, to be a success simply because the number of people receiving benefits at any given time was cut by half. In reality though, "welfare reform” severely limited the pursuit of educational opportunities.

\section{Conclusion}

This paper provides insight into undocumented, practical difficulties encountered by motivated low-income single mothers attempting to go back to school to complete postsecondary educational programs. Although the findings here shed light on the difficult educational paths tread by poor mothers, further research is needed to understand the applicability of these findings for other low-income single mothers. Qualitative, as well as quantitative research, is called for to further investigate obstacles to the educational pursuits of low-income single mother students.

What might be done to make education a more viable pathway out of poverty for poor mothers is an even more difficult question. In some ways, the obstacles outlined in this paper have their roots in early educational and career counseling experiences (or the lack thereof) in the schools attended by these low-income single mothers. Without advice from friends and family members who have attended college, for instance, institutional support becomes even more important. From a young age, many of these women did not understand college to be a viable option for them. The majority of interviewees had no close peers or family members who had attended four-year colleges. In fact, studies suggest that many low-income mothers would like to pursue a college degree but most doubt their ability to attain one (Bullock and Limbert 2003).

Further, all of our interviewees reported being advised against pursuing a college degree in a liberal arts field, because of the pressing need to make money. However, college is one of the key opportunities for the transmission of cultural capital the building of which could impact career and class status (Bourdieu 1964). Also, it is difficult to gauge problems associated with pursuing jobs and careers that do not align with personal interest. In fact, this may lead to further changes in direction that low-income single women can ill afford.

Presumably a centralized system of career counseling even after high school graduation would have benefited the low-income single mothers interviewed here. Often nontraditional, single mother students require individualized attention to remedy gaps in their education and help them to navigate the maze of educational options. Instead, we observed a conflicting array of information gleaned from caseworkers, counselors, friends, teachers, and the internet, which led to frequent changes of plans.

At some point, the majority of interviewees had pursued some type of short-term, vocational training program. While there is no question that a four-year degree offers the most significant benefit to a person's lifetime wages and employability (IWPR 
2008), research is also needed to determine what kinds of basic education, technical skills and job training courses are the most effective in helping low-income single mothers move forward. An evaluation of welfare-to-work policies found that in a sample of people who had not graduated from high school, those who participated in basic education combined with post-secondary education earned $47 \%$ more than those who received only basic education (Workforce Alliance 2002; Bok 2004, 47). For women who want to move past basic remediation, but for whom a college degree is not a viable option, it is important to choose the best vocational training available.

Perhaps what the data here suggest as the most vitally important to the success of lowincome single mothers in their pursuit of higher education is increased flexibility of educational institutions to meet the needs of single mother students. One of the mothers said of her experience attending a new college, “I don't feel real supported. I mean I'm coming in as a non-traditional student and I just realized how much you have to just do on your own, like there's no one to help." Single mother students have different needs, like arranging class schedules around childcare, which are not shared by traditional college students. Colleges often do not offer specific remediation programs to help students to catch up or fill the gaps created by stretches of time away from school. Counseling and community-building opportunities might also help to prevent feelings of isolation among low-income single mother students (Adair 2001). Educational institutions must be made aware of the experiences and specific educational needs of low-income single mother students, and the research here is a part of the effort to fill this gap in understanding.

\section{References}

Adair, V.C. (2001). Poverty and the (broken) promise of higher education. Harvard Educational Review, 71 (2), 217-239.

Adair, V. C., and Dahlberg, S. L. (2003). Reclaiming class: Women, poverty, and the promise of higher education in America. Philadelphia, PA: Temple University Press.

Blank, R.M. (2009). Economic change and the structure of opportunity for less skilled workers. In M. Cancin and S. Danziger (Eds.), Changing Poverty, Changing Policies. New York: Russell Sage Foundation.

Bullock, H. E., and Limbert, W. M. (2003). Scaling the socioeconomic ladder: Lowincome women's perceptions of class status and opportunity. Journal of Social Issues, 59(4), 693.

Christopher, K. (2005). A 'pauperization of motherhood'? single motherhood and women's poverty over time. Journal of Poverty, 9(3), 1-23.

Cox, K. L., and Spriggs, W. E. (2002). Negative effects of TANF on college

enrollment. Washington, DC: National Urban League Institute for Opportunity and Equality.

Deprez, L.S., Butler, S. S., and Smith, R. J. (2004). Securing higher education for women on welfare in Maine. In V. Polakow, S. S. Butler, L.S. Deprez and P. Kahn (Eds.), Shut-Out: Low-Income mothers and higher education in post welfare reform America. New York: SUNY Press. 
Institute for Women's Policy Research. (Feb 2008). Resilient and Reaching for More: Challenges and Benefits of Higher Education for Welfare Participants and Their Children. Washington, DC: Avis Jones-DeWeever \&Barbara Gault.

Institute for Women's Policy Research. (1998). Education and job training under welfare reform. IWPR Welfare Reform Network News, 9/10, 1-15.

Jimerson, S., Egeland, B., and Teo, A. (1999). A longitudinal study of achievement trajectories: Factors associated with change. Journal of Educational Psychology, 91(1), 116.

Mortenson, T. G. (2000). Poverty, race, and the failure of public policy: The crisis ofaccess in higher education. Academe, 86(6), 38-43.

Olson, S.L., and Banyard, V. (1993). "Stop the world so I can get off for a while": Sources of daily stress in the lives of low-income single mothers of young children. Family Relations, 42(1), 50-56.

Pearson, A. F. (2007). The new welfare trap: Case managers, college education, and TANF policy. Gender and Society, 21(5), 723-748.

Polakow, V. (2004). Shut out : Low income mothers and higher education in postwelfare America. Albany, NY: State University of New York Press.

Sands, R. G., and Nuccio, K. E. (1989). Mother-headed single-parent families: A feminist perspective. Affilia, 4(3), 25-41.

Seccombe, K., James, D., and Walters, K. B. (1998). "They think you ain't much of nothing": The social construction of the welfare mother. Journal of Marriage and Family, 60(4), 849-865.

Smith, D. E. (1997). From the margins: Women's standpoint as a method of inquiry in the social sciences. Gender, Technology and Development, 1(1), 113-135.

Strawn, J., and Martinson, K. (2000). Steady work and better jobs: How to help lowincome parents sustain employment and advance in the work force. Washington, DC: Manpower Demonstration Research Corporation. 